\title{
ロボットと食育者の相互作用に基づく 発達的学習モデルによる共同注意の獲得
}

\section{Acquisition of Joint Attention by a Developmental Learning Model based on Interactions between a Robot and a Caregiver}

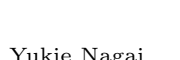 \\ 大阪大学大学院工学研究科 \\ Graduate School of Engineering, Osaka University \\ yukie@er.ams.eng.osaka-u.ac.jp, http://www.er.ams.eng.osaka-u.ac.jp/user/yukie/yukie-jp.html \\ 浅田 稔 \\ 大阪大学大学院工学研究科, 阪大フロンティア研究機構 \\ Graduate School of Engineering, Osaka University, HANDAI Frontier Research Center \\ asada@ams.eng.osaka-u.ac.jp, http://www.er.ams.eng.osaka-u.ac.jp/user/asada/asada-jp.html \\ 細田 耕同上) \\ Koh Hosoda hosoda@ams.eng.osaka-u.ac.jp, http://www.er.ams.eng.osaka-u.ac.jp/user/hosoda/indexj.html
}

keywords: cognitive developmental robotics, learning, joint attention

\section{Summary}

This paper presents a developmental learning model for joint attention between a robot and a human caregiver. The basic idea of the proposed model comes from the insight of the cognitive developmental science that the development can help the task learning. The model consists of a learning mechanism based on evaluation and two kinds of developmental mechanisms: a robot's development and a caregiver's one. The former means that the sensing and the actuating capabilities of the robot change from immaturity to maturity. On the other hand, the latter is defined as a process that the caregiver changes the task from easy situation to difficult one. These two developments are triggered by the learning progress. The experimental results show that the proposed model can accelerate the learning of joint attention owing to the caregiver's development. Furthermore, it is observed that the robot's development can improve the final task performance by reducing the internal representation in the learned neural network. The mechanisms that bring these effects to the learning are analyzed in line with the cognitive developmental science.

\section{1.は じめに}

人間の乳幼児は, 環境, 特に養育者との相互作用を通し て,生後数年の間に，樣々で複雑な認知機能を獲得する。乳 幼児の認知発達過程については, 認知科学や発達心理, 神 経科学の分野で広く研究されている [Elman 96, Johnson 97, 乾 01] が, 弚の大半は乳幼児の表出する運動やニュー ロンの活動パターンの観察など , 分析的なアプローチで ある.これに対して, 近年, 工学的視点から構成論的ア プローチによって, ロボットに乳幼児と同樣の発達過程 を再現することで, 発達メカニズムの理解を目指した研 究か試みられている. Asada et al. [Asada 01] は人間の 認知, 発達, 神経科学の知見に基づいたロボットの設計 指針として, 認知発達ロボティクスを提唱した . 認知発 達ロボティクスでは, ロボットが物理的身体をもち，光 れを通して環境と相互作用することによって，いかにし て認知機能が発生してくるのか, また，乥のような機能 をいかにして工学的に実現するのか，という構成論的な
議論がなされる.小嶋ら [小嶋 01b] は幼児の発達研究を 概観し，発達は養育者との相互行為を通して達成される， という基本理念のもとに, 社会的に発達する赫ちゃんロ ボットの可能性について考察した . 彼らは, 赤ちゃん口 ボットが生得的な動機づけをもち, 養育者との間で原初 的な相互行為を形成し，弚れを基に環境を探索すること によって, 社会的知能か獲得されると提言した . また ここ うしたアイディアに基づく社会的に発達するロボットが， Infanoid [Kozima 01a] や Kismet [Breazeal 00], Cog [Scassellati 02] , Babybot [Metta 01] として開発されて いる .

ロボットもしくは人間の幼児が , 養育者との間で相互 行為を形成する上で, 重要な機能の一つに共同注意の能 カが挙げられる [Butterworth 91] . 共同注意は, 他者が 注意を向けている対象と, 同じ対象に注意を向けること であり，幼児は養育者との間で共同注意を実現すること で, 養育者から多くの知識を学ぶことが可能になる . ま 
た，この共同注意の能力自体も，幼児は養育者との相互 作用を通して学習によって獲得していることが知られて いる [Moore 95] . しかし，これまでに開発されたロボッ 卜 Infanoidや Kismet, $\operatorname{Cog}$ では , 共同注意の機能は設 計者によってあらかじめ組み込まれており，共同注意が いかにして学習されるのかについて, 構成論的アプロー チから取り組んだ研究は見られない .

また, 認知発達研究において注目されていることの一 つとして, 幼児が複雑な環境とのインタラクションの中 で，いかにして効率的な学習を実現しているのかという 問題がある．これに関して，「発達が学習の一助となる」 ことが示唆されている、特に, 言語学習の分野では, 幼 児自身の認知・記憶能力の発達と, 学習を援助する養育者

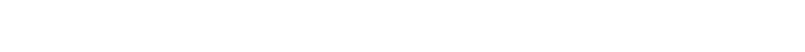
雑さを緩和する適切なフィルタとなり, 効率的な言語学 習を実現していると言われている [Newport 90, Elman 96]. 乥して, これを認知発達ロボティクスの研究に応用 した例として , 赤ちゃんロボット Babybot のリーチング 運動の学習 [Metta 99] や跳躍性眼球運動の学習 [Metta 01]に関する研究が挙げられる . また, 両眼視差の学習に 発達的アプローチを応用した例 [Dominguez 01] や，認 知発達研究ではないが, ロボットのサッカータスクの学 習に適用した例 [Uchibe 98] も見られる.しかし，これ らの研究では, 結果として発達か効率的な学習を実現し たという現象面の理解にとどまっており，発達における 何の因子が効率化において重要であるのか, また発達が 学習モデルの内部構造にどのような影響を与えているの かというメカニズムの理解には至っていない .

弚こで, 本研究ではロボットが養育者との相互作用を通 して共同注意の能力を獲得するためのモデルとして, 発 達的学習モデルを提案し，構成論的アプローチから，口 ボットがどのような認知発達プロセスを経て, 効率的に 共同注意を学習していくのかというメカニズムの理解を 試みる.提案モデルは、発達がタスク学習の一助となる」 という認知発達学の知見に基づき, 学習と発達の二種類 のメカニズムをもち, 学習のプロセスではタスクを習得 し, 弚れと並行して, 発達のプロセスではロボットと養 育者の機能的変化を起こすことによって，効率的かつ高 性能な共同注意の学習を実現するものである．また，本 研究ではロボットを用いた実験を通して, 認知発達学の 知見を実証的にサポートするとともに，構成論的立場か ら幼児の発達研究に示唆を与えることを期待する. 本論 文では，まず 2 章で発達の定義と光れを引き起こすトリ ガとの関係を述べ, 3 章で共同注意問題について説明す る.次に, 4 章において, 本研究で提案する発達的学習 モデルについて説明し，5章で提案モデルの学習性能を 評価した実験を示す. 乥して最後に，6 章で本研究のま とめと今後の課題を述べる .

\section{2. 発達とは}

\section{$2 \cdot 1$ ロボットの発達と養育者の発達}

一般的に「発達は個体の成熟化や複雑化, 有能化といっ た方向性をもつ変化である」と考えられる . 共同注意に 代表されるコミュニケーション機能の学習過程において は, 学習者であるロボット自身の内部機能の成熟化と, 学 習を援助する養育者側の機能的変化が，同時に起きてい ると考えられる.ここでは, 前者をロボットの発達 , 後 者を養育者の発達と呼び，以下のように定義する．

ロボットの発達： ロボットの知覚・運動機能が , 未熟な 状態から徐々に成熟状態へ近付いていくこと.

養育者の発達： 養育者が, ロボットに教えるタスクの

難易度を，簡単なレベルから徐々に困難なレベルへ 変化させていくこと .

本研究で提案する発達的学習モデルは, これら二つの発 達メカニズムを有する学習モデルである．

\section{$2 \cdot 2$ 発達を引き起こすトリガ}

発達が何をトリガとして生じているのかという問題に は，次の二つの考え方がある [Bremner 94] . まず一つは， 生得的要因によって決められているという説と，もう一 つは，環境からの影響を受けて発達が引き起こされると いう説である . 前者は，個体の発達メカニズムが遺伝的， 生得的に埋め込まれ，発達の生起時期も予め時間的スケ ジュールとして定義されていることを意味する．この場 合，個体は環境での行動経験には一切関係なく，時間の 経過に沿って機能的変化を生じることになる．これに対 して後者は, 個体か環境と相互作用し, 弚の行動経験か ら樣々な能力を学習することによって，個体内部での機 能の成熟化が起きるという考え方である．つまり，学習 が進展することによって，弚の能力に見合ったレベルま で機能が発達し，また光れによってさらに学習が進む，と いう相補的な関係になる。

本研究では, これら二種類の発達トリガのうち, 後者 のメカニズムを採用する．つまり，ロボットが養育者と のインタラクションを通して共同注意を学習し, 弚の学 習の進展 , つまりパフォーマンスの向上がロボットと養

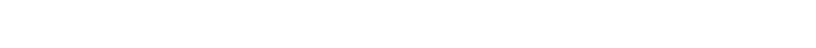
ロボットと養育者の発達レベルに応じたタスク学習が実 現され，学習の効率も高まるものと期待される.

\section{3. 共 同 注 意}

共同注意は，自己，他者，対象の三項関係において，自 己が他者の注意対象を環境中から発見し，同時に同じ対 象に注意を向けること」として定義される $[$ Butterworth 91] .この関係を，自己をロボット，他者を人間の養育者 として表現したものを图 1 に示す.まず，(1) ロボットは 養育者の樣子をカメラを通して観察し, 顔や視線の向き 


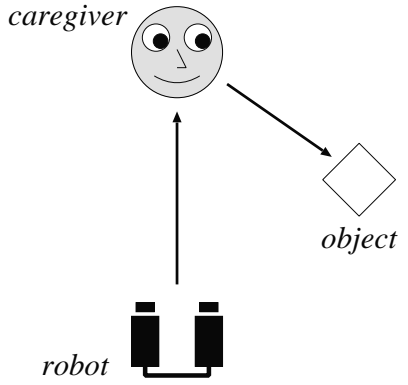

(1)

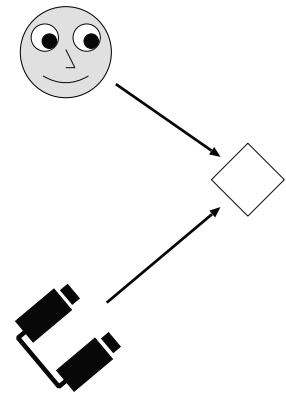

(2)
図 1 ロボットと養育者間の共同注意 . ロボットは, (1) 養育者を 観察し，養育者が注意を向けている方向を推定する．光して， (2) 推定した方向へカメラを向けることによって, 対象物を 発見し，共同注意を成立させる .

から養育者の注意方向を推定する。乥して，(2) 推定し た方向へカメラを向けることによって，養育者が見てい ると予測される対象物を環境中から発見し，共同注意を 成立させる .

共同注意の機能をもつことによって，ロボットは養育 者との非言語的なコミュニケーションを実現し，人間の 幼児のように，養育者から多くの知識を学ぶことが可能 になる．また，この共同注意に基づいた他者との状況の 共有という経験を通して，ロボットは心の理論 [BaronCohen 95] と呼ばれる他者理解の能力を獲得し，真に社 会的な存在となることか期待される .

\section{4. 共同注意のための発達的学習モデル}

本研究で提案する共同注意のための発達的学習モデル を図 2 に示す . 本モデルは, ロボットのタスク学習メカニ ズムとしてのニューラルネットワーク $(\mathrm{NN})$ と，養育者 のタスク評価器の二つのモジュールから構成される．光 して, 各モジュールには, 学習の進展をトリガとして引 き起こされる発達のメカニズム (ロボットの発達メカニ ズムと養育者の発達メカニズム) が存在する .

共同注意タスクの手順として，ロボットは，まずある 対象物に注意を向けている養育者を観察し (図 1 (1)の 状況），光の時のカメラ画像を $\mathrm{NN} へ$ の力として獲得 する. 乥して, 入力画像から網膜層, 視覚野層を介して, 運動出力として, 養育者が注意を向けているものと同 じ対象物を注視するための, カメラの変位角度を生成す る (図 1 (2) の状況) .一方, 養育者は, ロボットが表出 したカメラの視線方向と, 対象物が置かれた位置を観察 し，弚の間の誤差を推定する．光して，光の誤差に基づ き, 共同注意タスクの成否を表す評価値 (1 or 0) を決 定して，ロボットに付与する．ロボットは養育者から与 えられた評価値に基づいて，NN の学習を行なう．また， 学習の経過と並行して, ロボットと養育者の発達が乥れ

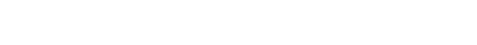

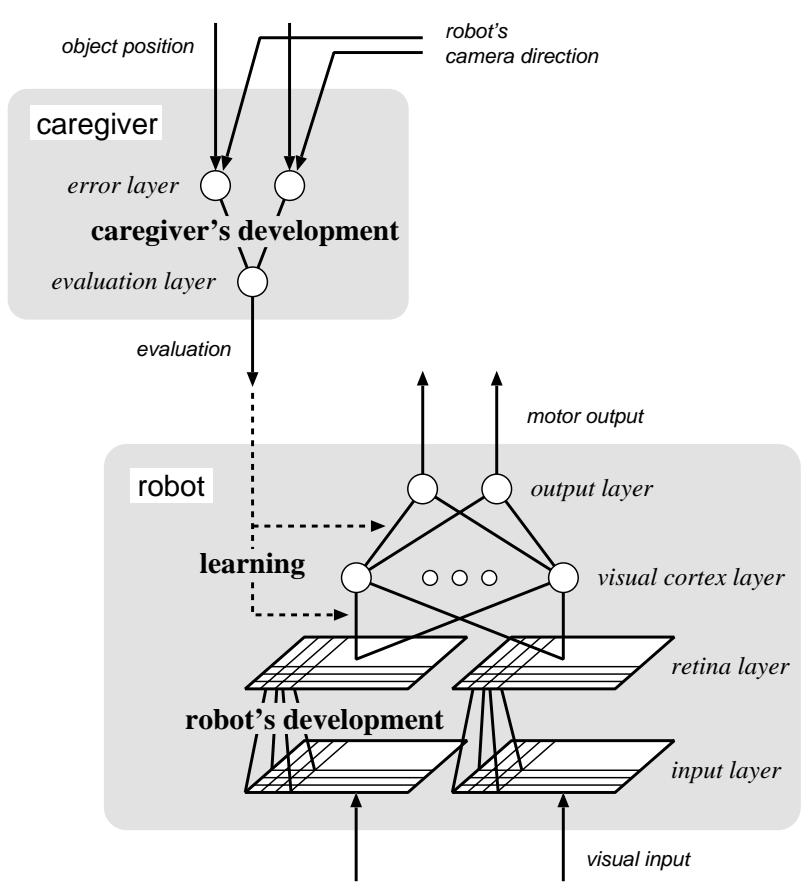

図 2 共同注意のための発達的学習モデル

以降の節で, タスク学習のメカニズムと, 養育者と口 ボットの発達メカニズムについて順に説明する .

\section{$4 \cdot 1$ 学習メカニズム}

ロボットは, NN の網膜層 一 視覚野層間と, 視覚野層一 出力層間の結合荷重 $W_{k}^{r c}, W_{k}^{c o}$ を, 養育者から与えら れる評価値 $V_{k}$ に基づいて学習する .ここで, $k$ は学習ス テップである .

評価値 $V_{k}$ は， $V_{k}=1$ のときタスクが成功したことを， $V_{k}=0$ のとき失敗したことを意味する .ロボットは夕 スクの成否に基づき, 次学習ステップ $(k+1)$ の結合荷 重を，

$$
W_{k+1}^{r c, c o}= \begin{cases}W_{k}^{r c, c o}, & \text { when } V_{k}=1 \\ W_{k}^{r c, c o} \pm \Delta W, & \text { when } V_{k}=0\end{cases}
$$

として更新する．ここで， $\Delta W$ は微小なランダム值であ る、つまり，タスクが成功したときには，ロボットは光 の時点の結合荷重を保持し, 失敗したときには僅かに変 更するという方法である.

\section{$4 \cdot 2$ 養育者の発達メカニズム}

学習の経過と並行して, 養育者はタスクを評価する際 の評価基準を, ロボットのタスクパフォーマンスに応じ て徐々に変更するという発達的変化を起こす. タスクの 評価方法として, 養育者は, まずロボットの運動出力で あるカメラの視線方向と, 対象物の位置を観察し, 光の 間の角度誤差 $e_{k}$ を推定する. 乥して，この $e_{k}$ をもとに， 
次式により $V_{k}$ を決定する .

$$
V_{k}= \begin{cases}1, & \text { when } e_{k} \leq \theta_{k} \\ 0, & \text { when } e_{k}>\theta_{k}\end{cases}
$$

ここで, $\theta_{k}$ はタスクの許容誤差を示す値で， ロボットの 出力誤差の平均値 $E_{k}\left(=\right.$ ave. of $\left.e_{k}\right)$ を用いて,

$$
\theta_{k}=E_{k-1}-\epsilon \quad(\epsilon: \text { a small value })
$$

と定義される.つまり，養育者はロボットの平均出力誤差 よりも僅かに小さな值を評価基準に，光れよりも誤差が 小さい場合には評価値 1 を，大きい場合には 0 をロボッ 卜に与えることによって，ロボットのタスクパフォーマ ンスに合わせたタスク評価を行なう．また， $\theta_{k}$ を更新す るタイミングは, 学習が進展したとき，つまり

$$
E_{k-1}<\min E_{j} \quad(0 \leq j<k-1)
$$

のときとする .これにより，ロボットの出力誤差が一時 的に増加することによる発達のマイナス方向への変化を 防ぎ，学習の進展と同期した発達を実現する。

養育者の発達の樣子を図 3 の右側に示す . 図中の斜線 で表示された扇型の領域が， $\theta_{k}$ で定義される共同注意夕 スクの評価範囲を表しており, ロボットの運動出力 (カ メラヘッドから伸びている矢印) がこの範囲内に入れば 評価値 1 , 範囲外であれば 0 がロボットに与えられるこ とになる．この図から，(a) 学習初期には扇型の領域が 広く, 誤差の大きな運動出力に対しても評価値 1 を与え る，つまり，タスクの難易度を低く設定していることが 確認できる．光して，学習の進展に伴い，徐々にこの扇 型の領域を狭めていくことによって，(b) 学習後期では より難易度の高い，正確な共同注意タスクの学習を実現 していることか理解できる .

\section{$4 \cdot 3$ ロボットの発達メカニズム}

タスク学習の進展と同期して, ロボット側では視覚機 能の発達が, NN の入力層 - 網膜層間の結合荷重の変化 として生じる．両層における情報を画像情報とし，学習 ステップ $k$ における両層間の結合荷重 $W_{k}^{i r}$ を, ガウス関 数を用いて次式の空間フィルタとして表現する.

$$
W_{k}^{i r}=\exp \left(-\frac{\left(x-x_{c}\right)^{2}+\left(y-y_{c}\right)^{2}}{2 \sigma_{k}{ }^{2}}\right)
$$

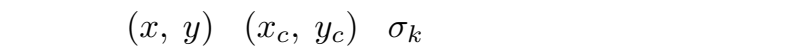
の位置, 空間フィルタを施す注目画素位置, 空間フィルタ の鮮明度を表す值である. 光して, $\sigma_{k}$ の值を，学習開始 時と前学習ステップでのロボットの平均出力誤差 $E_{i n i t}$, $E_{k-1}$ と，学習終了時の許容誤差 $E_{f i n}$ を用いて,

$$
\sigma_{k}=\sigma_{\text {init }}\left(\frac{E_{k-1}-E_{\text {fin }}}{E_{\text {init }}-E_{\text {fin }}}\right)
$$

として表現する.ここで, $\sigma_{i n i t}$ と $E_{f i n}$ は光れ光れ視覚発 達の初期状態と終了条件を示す定数として, 学習開始時に 設計者が規定するものである.上記のような $\sigma_{k}$ の定義は，

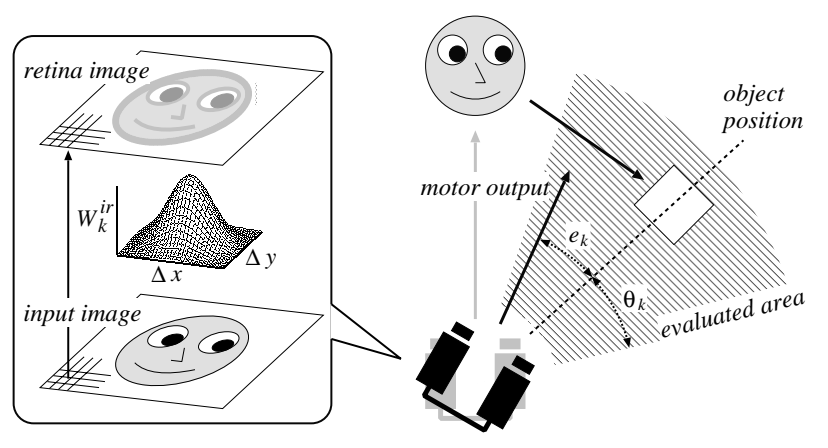

(a) 学習初期

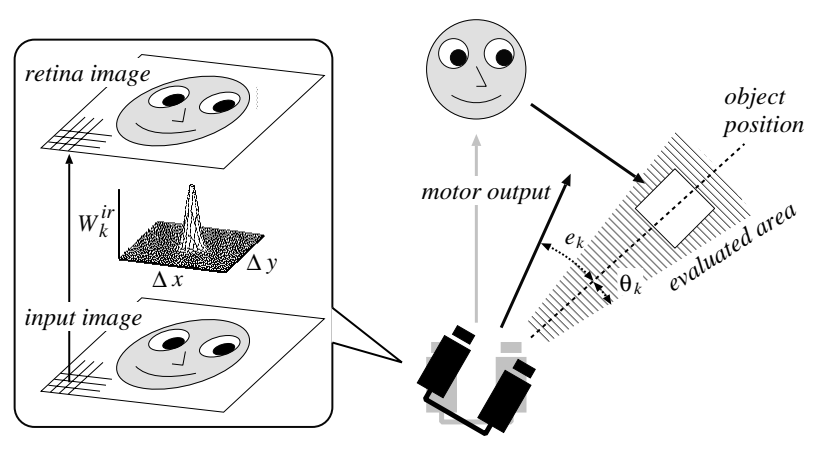

(b) 学習後期

図 3 ロボットの視覚発達 (左側) と養育者の発達 (右側)

学習初期に $E_{k-1} \approx E_{i n i t}$ であることから, 空間フィルタ が平滑率の高いフィルタとなっていたのが , 学習の進展 とともに出力誤差が減少し, 学習後期には $E_{k-1} \approx E_{f i n}$ となることによって，フィルタが透過フィルタへ近付く ことを意味する．また， $\sigma_{k}$ を更新するタイミングは，養 育者の発達を表現した $\theta_{k}$ の更新と同樣に，

$$
E_{k-1}<\min E_{j} \quad(0 \leq j<k-1)
$$

のときとする .これによって，学習の進展と同期した， また養育者の発達とも同期したロボットの発達を実現す る.尚，本メカニズムは，人間の幼児の視覚発達につい て示唆されている「網膜画像の解像度は, 弚れを処理す る皮質神経系の処理能力によって決定される」という説 [Bremner 94]に基づいており，認知科学を構成論的に議 論する研究として意味をもつものである .

図 3 の左側にロボットの視覚発達のメカニズムを模式 的に示す . 入力画像と網膜画像間にガウス関数で表現さ れる空間フィルタが存在し，このフィルタの傾きが変化 することによって，視覚機能の発達を表現している．つ まり, (a) 学習初期には空間フィルタが平坦で, 網膜画像 が不鮮明であったのが，(b) 学習後期にはフィルタが急 勾配になり，透過フィルタと同等になることによって入 力画像が光のままの鮮明な状態て網膜に投影される，と いうメカニズムである . 


\section{5. 実 験}

\section{$5 \cdot 1$ 実 験 設 定}

提案する発達的学習モデルを実ロボットへ実装し，学 習性能を評価する実験を行なった . 実験環境を図 4 (a) に，実験に用いたロボットのカメラヘッド部分を同図 (b) に示す.ロボットと養育者が一対一で対面し，各々の位置 は固定とする．養育者は対象物を手に持ち，樣々な位置 へ動かして，対象物の方向へ視線 (顔)を向ける.ロボッ 卜は乥の樣子をカメラを通して観察し，養育者の顔画像 を $\mathrm{NN} へ の 入 力 ，$ 対象物を注視するために動かすカメラ ヘッドの変位角度を出力として, 養育者から与えられる 評価値に基づいて学習を行なう．尚，今回の実験で用い る NN の各層のニューロン数は, 入力層 750 個（顔領域 を抽出した $30 \times 25$ 画素の画像)，網膜層 750 個 +1 個 (閾值設定用)，視覚野層 7 個 +1 個 (閾値設定用)，出力 層 2 個 (パン角，チルト角) である.視覚野層のニュー ロン数は, 予備実験から , 学習後の出力誤差が $5 \%$ 以下で あるという条件のもとで最少の数としている . また ,才 フラインでの実験を行なうため，ロボットのカメラヘッ ドの最大変位角度 (パン方向 \pm 45 度, チルト方向 \pm 25 度) を光れ光れ 20 度ごとに離散化し，15 方向について 各 5 個, 計 75 個の学習データを獲得して, 弚れを繰り 返しロボットに与えることで学習を実現する。

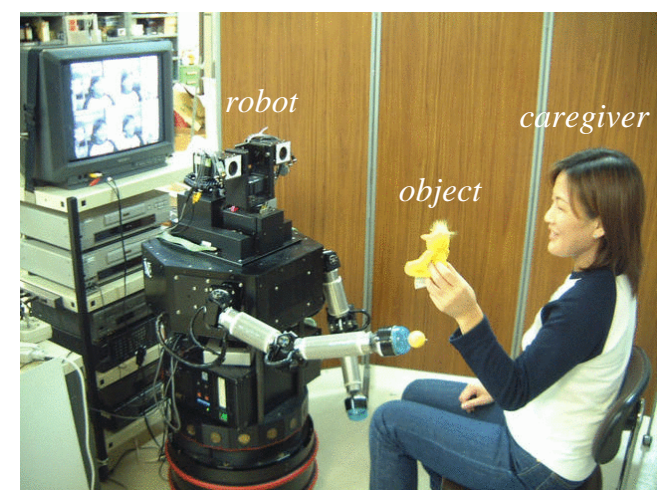

(a) 実験環境

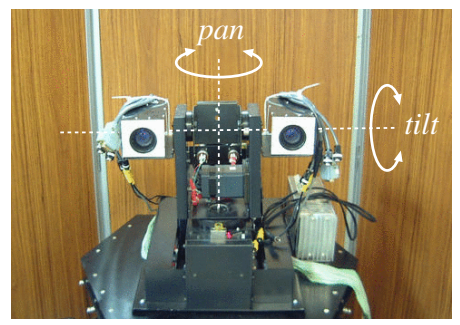

(b) ロボットのカメラヘッド

図 4 実験設定
以上の方法で, 学習と発達メカニズムのパラメータ設 定を樣々に変化させて実験を行ない, 学習速度と学習後 のタスクパフォーマンスについて比較した . 今回 , 50 パ ターン以上のパラメータ設定で実験を行なった結果, 全 ての条件において同樣の特性か観察されたので, 以降の 節では光の一例として，式 (1)〜 (8) で用いる定数を光れ

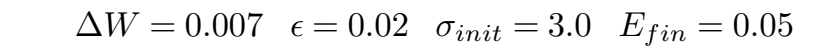
$\epsilon^{\prime}=0.02$ と設定したときの実験結果を示す.

\section{$5 \cdot 2$ 学習速度の評価}

発達メカニズムによって学習速度にどのような効果が 現れるか検証するため, 本研究て提案した発達的学習モ デルと，発達メカニズムをもたない（既に成熟したメカ ニズムをもつ) モデルの学習速度を比較した .ここで, 成 熟したメカニズムとは，養育者側においてタスクの評価 基準を示す式 (3) が，

$$
\theta_{k}=\epsilon^{\prime} \quad\left(\epsilon^{\prime}: \text { a small value }\right)
$$

であること，または，ロボット側において入力層 - 網膜 層間の空間フィルタを表す式 (5)が，

$$
W_{k}^{i r}= \begin{cases}1, & x=x_{c}, y=y_{c} \\ 0, & x \neq x_{c}, y \neq y_{c}\end{cases}
$$

であることに相当する．つまり，養育者はタスクの難易 度を学習初期から高く設定し, また, ロボットの視覚は 学習初期から網膜層に鮮明な画像を獲得できていること を意味する .

ロボットと養育者の発達メカニズムの有無による四種 類の学習モデルについて, 学習速度を比較した . 学習過 程における NN の出力誤差の推移を図 5 に示す .ここで， $R C$-dev. model は, 本研究で提案したロボットと養育者 の発達メカニズムを有する学習モデル，R-dev. model, C-dev. model は, 光れボットのみ，または養育 者のみの発達メカニズムをもち，他方は既に成熟してい るモデル, Matured model はどちらの発達メカニズム ももたない，つまり，ロボット，養育者ともに，既に成 熟したメカニズムをもつ学習モデルである．これより， 四種類のモデルの学習速度を比較すると, 養育者の発達 メカニズムが付加されることによって， Matured model が C-dev. model の曲線へ, また $R$-dev. model が $R C$ -

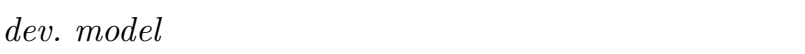
速化されていることか確認できる .これは, 養育者がタ スクの難易度を， ロボットのパフォーマンスに応じて徐々 に難しくしていくことによって，段階的な学習を実現し たためと考えられる.一方, ロボットの発達メカニズム に関しては, Matured model が R-dev. model の曲線へ， また C-dev. model が RC-dev. model の曲線へと変化 しており，学習を遅延させてしまっている，つまりマイ ナスの効果を与えていることか観察される.これは, 学 習の初期・中期段階ではロボットの視覚機能が低いこと 


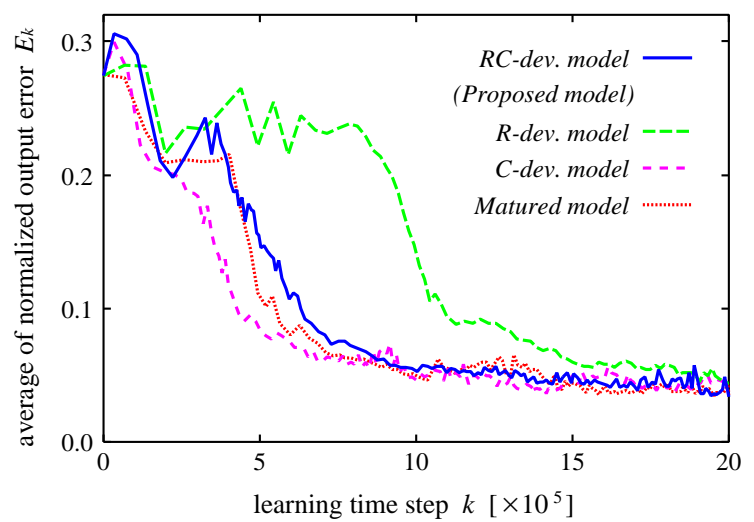

図 5 学習過程における $\mathrm{NN}$ の平均正規化出力誤差の推移

によって入力画像上の情報が奪われ，養育者の注意方向 を正確に推定できなかったためと考えられる .

\section{$5 \cdot 3$ 発達のトリガと学習速度の関係}

学習速度に関して, 発達のプロセスだけではなく, 発 達を引き起こすトリガがどのような影響を与えているの かを検討した . 本研究で提案したモデルでは, ロボット と養育者の発達がともに学習の進展をトリガとして引き 起こされる.これに対して，発達が予め定義された時間 のスケジューリングに沿って進行する場合を考え，両パ ターンでの学習速度を比較した。

図 6 に各発達トリガでの NN の誤差推移のグラフを示 す . (a) は学習の進展をトリガとした場合, (b) は時間ス ケジューリングに沿って発達が起きる場合である . (b)の 発達の時間スケジュールは, 数回の試行錯誤実験の中で 最も学習高速化の効果を現したものを採用した．乥れぞ れ，太い実線が各学習モデルの出力誤差の推移，細い破 線が兴のときの養育者の発達を表す $\theta_{k}$ の変化を示してい る.ここでは，ロボットの発達を示す線は省略した．図 6 の比較から, 発達のトリガと学習速度の関係について 以下のことか確認できる .

・養育者の発達メカニズムは, 乥のトリガに依らず学 習を高速化させる可能性をもつ．

・ただし，発達が時間スケジューリングに沿って生じ る場合は, 学習の高速化の効果は発達のスケジュー ルに大きく依存するため，適切な設定をするには試 行錯誤を必要とする. 乥して, 最も学習が高速化さ れる場合でも，弚の効果の大きさは学習の進展と同 期した発達による効果と同程度である。

・これに対して, 学習の進展をトリガとして発達が生 じる場合は, 発達が学習と同期して進行し, 各学習 ステップでのパフォーマンスに応じた適当な難易度 のタスク学習を実現するため, 確実に学習が高速化 される $(\epsilon= \pm 0.05$ の範囲内でこれを確認)．

以上の結果から, 学習速度に関しては, 本研究で提案した 発達的学習モデルの養育者の発達メカニズムが, 学習の

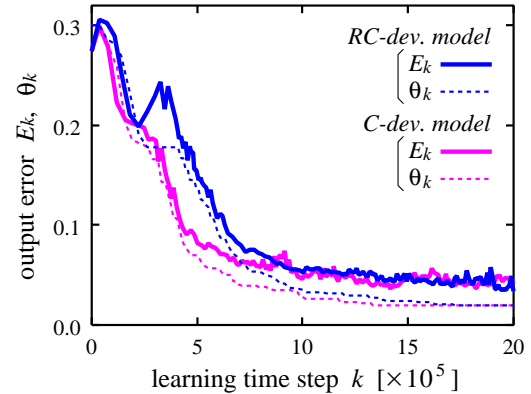

(a) 学習の進展をトリガとして発達が起きる場合

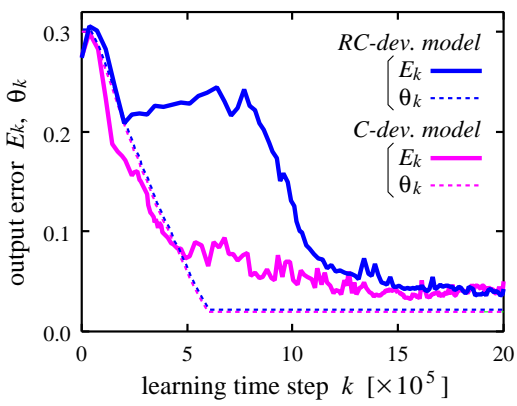

（b）時間スケジュールに沿って発達が起きる場合

図 6 発達を引き起こすトリガと学習速度の関係

高速化という点で有益な効果を挙げることか確認できた .

\section{$5 \cdot 4$ 学習後のタスクパフォーマンスの評価}

次に，学習速度の評価に用いた四種類の学習モデル $R C$-dev. model, $R$-dev. model, $C$-dev. model, Matured model について, 学習後のタスクパフォーマンスの評価 を行なった . まず, 图 5 のグラフから学習データに対す る最終的な誤差の值を比較すると，どの学習モデルにつ いてもほぼ同じ値を示していることが確認できる．

乥こで, 学習後の各モデルの NN に対して, 学習に用 いたデータとは異なる未知の入力データ (養育者一定， 対象物の提示位置変化, 照明条件変化) を 45 個与えて, 兴のときの出力誤差を比較した . 図 7 に各モデルの平 均出力誤差と標準偏差のグラフを示す．これより， $R C$ dev. model と $C$-dev. model, 光して $R$-dev. model と Matured model を乥れ光れ比較すると，学習モデルにロ ボットの発達メカニズムが付加されることによって, 学 習後の出力誤差が減少する，つまりタスクパフォーマン スが向上していることが確認できる．また，これらの結 果についてテューキーの方法 [石村 92] により統計的検 定を行なったところ, 有意水準 $5 \%$ で，ロボットの発達 メカニズムをもつモデルともたないモデルとの全ての組 合せの間に有意な差があることが認められた .このよう な結果は, 学習速度の点ではマイナスの効果を与えてい 

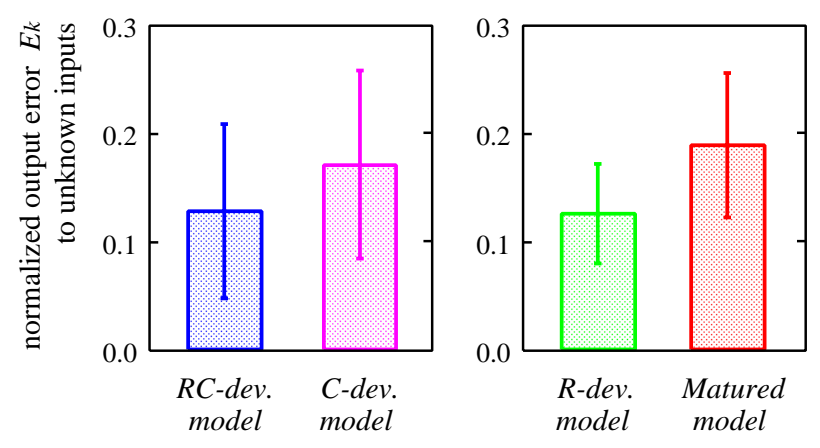

図 7 学習後の $\mathrm{NN}$ の未知入力に対する平均出力誤差

たロボットの視覚機能の未熟さが, 学習初期・中期の段 階で入力画像を平滑化することによって学習データに含 まれる誤差を吸収し，より沉化性の高い能力の獲得を実 現したためと考えられる .

\section{$5 \cdot 5$ 学習後の NN の内部表現とタスクパフォーマンス の関係}

ロボットの発達メカニズムによるタスクパフォーマン スの向上について，より具体的なメカニズムを理解する ため, 学習で得られた NN がどのような認識を行なっ ているのか, NN の内部表現を観察した . 図 8 に学習後 の NN に樣々なパターンの未知入力データ $(5 \cdot 4$ 節と同 樣)を 45 個与えたときの，視覚野層二ューロンの平均活 性度と標準偏差のグラフを示す．ここでは, 閾値設定用 ニューロンを除く 7 個のニューロン $(\# 0 \sim \# 6)$ につい て表示した .この結果から注目す心゙き点は, 各学習モデ ルが標準偏差 0 のニューロン, つまり認識に一切利用し ていないニューロンをもつことである.$R C$-dev. model では \#2 と \#3 のニューロン, $R$-dev. model では \#3 と \#6, Matured modelでは \#2 のニューロンが弚れに 相当する. 光して, この未使用ニューロンの数が, 学習 モデルにロボットの発達メカニズムが付加されることに よって，増加していることも確認できる．また，パラメー 夕設定を変化させての 50 回以上の学習実験の結果でも， 未使用ニューロンの平均数は光れ光れ $R C$-dev. model : 1.2 個，R-dev. model: 1.2 個，C-dev. model：0.7 個， Matured model: 0.6 個となっており，ロボットの発達メ カニズムによって内部表現がコンパクトになっているこ とが分かる.以上より, ロボットの発達とタスクパフォー マンスの関係について考察すると，

・学習モデルがロボットの視覚発達のメカニズムをも つことによって，学習初期・中期の段階で入力デー タが平滑化される，

・て , 平滑化によって入力画像における変化量の 大きな成分 (主成分) のみが抽出され，視覚野層で はこの主成分空間上での解探索が行なわれる，

・午の結果, 認識に必要とする視覚野層ニューロンの 数が減少し, 学習データに含まれる誤差も吸収され，

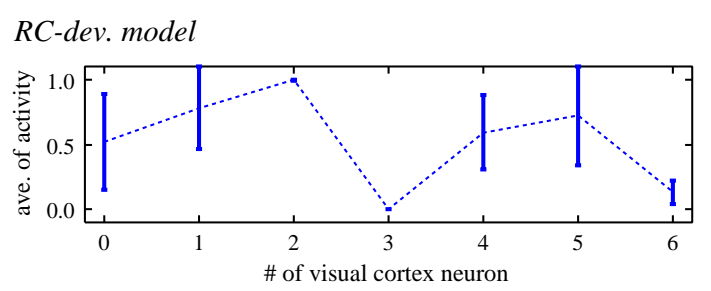

$R$-dev. model

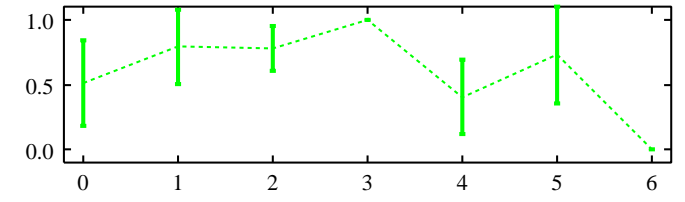

C-dev. model

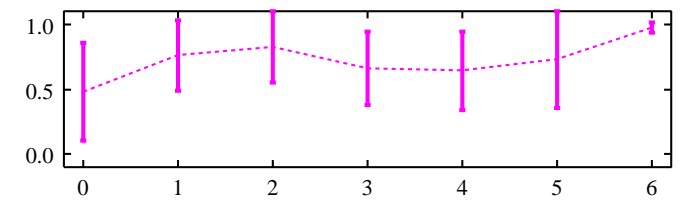

Matured model

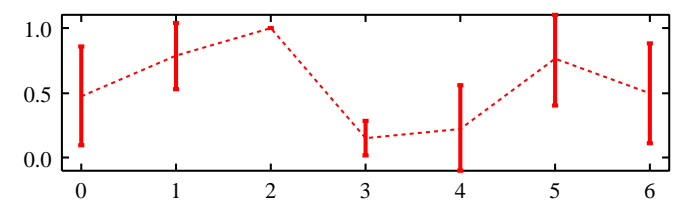

図 8 学習後の視覚野層ニューロンの平均活性度と標準偏差

$\mathrm{NN}$ はより汎化能力の高いものになる， と推測される．つまり，ロボットの発達による NN の内 部表現のコンパクト化が, タスクパフォーマンスの向上 の要因と考えられる

\section{$5 \cdot 6$ 共同注意の実験}

最後に，提案モデルの学習で得られた NN を用いて， 共同注意の実験を行なった . 実験環境は図 4 (a) に示し た通りである、ロボットが学習後の NN を用いて養育者 の注意方向を推定しているときの，ロボットのカメラ画 像を図 9 に示す. 弚れ光れ, ロボットの左カメラで観察 した画像である . 養育者の顔の上に描かれた四角い枠が， テンプレートマッチング法で検出された養育者の顔の位 置で, この部分の画像がロボットの $\mathrm{NN}$ へ入力となる . 乥して, 養育者の眉間から伸びた直線が NN の出力, つ まり養育者が見ている対象物と同じものを注視するため の, ロボットのカメラヘッドの変位角度を表している.光 れぞれ，直線の $x$ 軸方向成分がパン角の大きさ, $y$ 軸方 向成分がチルト角の大きさに相当する . ロボットはこの 直線の方向へカメラを回転させることによって, 養育者 が注意を向けている対象物を環境中から発見することが できる .

本実験では, ロボットがカメラ画像中心から $1 / 4$ の範 囲内に対象物を捉えることができたときに共同注意は成 功したと判断し, 弚の基準のもと, 発達的学習モデルで 獲得された NN を用いて，95\% (19/20 回) の確率で共 

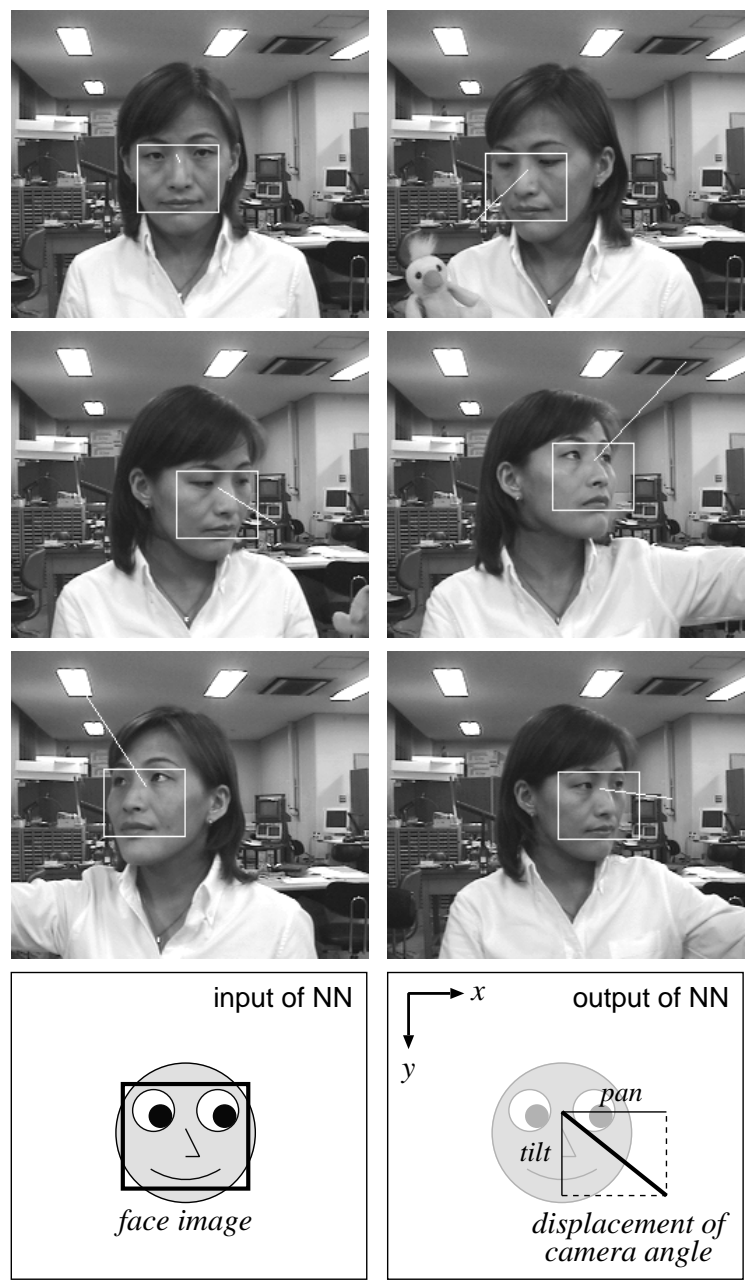

図 9 共同注意の実験結果

同注意が実現可能であることを確認した . ただし，今回 の実験では一定の養育者に対してしか学習を行なってお らず, 学習で得られた $N N$ も弚の養育者のみにしか対応 することができなかった . 乥こで, 今後は複数人の養育 者を対象とした実験を行なうことで，より共同注意の本 質を捉えるような NN の獲得を目指す．

\section{6. おわりに}

本研究では, ロボットが養育者との相互作用を通して 共同注意の能力を獲得するためのモデルとして, 発達的 学習モデルを提案した. 本モデルは認知発達研究で示唆 されている「発達がタスク学習の一助となる」という考え に基づき，タスクを習得するための学習のメカニズムと， ロボットと養育者の二種類の発達メカニズムから構成さ れる. 乥して, 学習の進展が二種類の発達を引き起こす トリガとなり，学習と発達が同期して進行するという特 徵を有する . 本論文では, 提案したモデルを実ロボット へ実装し, 学習性能を評価する実験を行なった結果, 以 下のことが確認された .

・ロボットは養育者との相互作用を通した学習によっ
て , 共同注意の能力を獲得することができる．

・養育者がタスクの難易度を徐々に困難なレベルへと 変化させるような発達のメカニズムをもつことによっ て, 学習は加速される.さらに, 養育者の発達が学 習の進展をトリガとして起きることによって, 学習 の高速化の効果は増大する .

・学習の進展と同期してロボットの視覚機能が発達す ることによって, 学習後の NN の内部表現がコンパ クトになる. 乥して，より抽象化の高い認識を実現 することで, タスクパフォーマンスが向上する . つまり，提案した学習モデルに含まれる二種類の発達メ カニズムが, ともに学習性能の向上に寄与したという結 果である. 弚して，これらの結果は認知発達学における 知見を実証的にサポートしているとともに, 発達と学習 の同期性が重要であること，また，発達によって学習モ デルの内部表現がより抽象化され得ることを示しており， 構成論的立場から幼児の発達と学習メカニズムの理解に 示唆を与えるものと期待する .

今後は, 発達のプロセスが学習に与えた樣々な効果に ついて，より詳細な分析を行なっていく.例えば，ロボッ 卜の視覚機能の未成熟段階において, 入力画像の抽象化 がいかにして行なわれたのかという問題や，ロボットの 視覚発達によって生じる学習曲線の逆 U 字型変化 (図 5 R-dev. model 参照) では, どのような内部機能の変化が 起きているのかという問題が挙げられる.特に, 学習曲 線の逆 U 字型変化は，人間の幼览の場合でも類似した現 象か観察されており [多賀 02], 非常に興味深い問題であ る.また, 別の課題として, 弚も光も共同注意の機能がど うして学習されるのか, ロボットはなぜ養育者の注意方 向を推定し，共同注意を行なおうとするのか，という疑 問がある .これは，真に社会的に発達するロボットを研 究していく上では避けて通ることのできない問題で, こ のメカニズムか理解できれば, 幼児の認知発達研究にも 大きな示唆が与えられるものと考えられる . 今後は , よ り幼児の学習・発達のプロセスに沿った条件で, ロボッ 卜に共同注意を学習させ, 上記に挙げた課題に取り組ん でいく予定である .

謝辞

本研究の一部は, 21 世紀型革新的先端ライフサイエン ス技術開発プロジェクト, 萌芽・融合開発プログラム「動 的インタラクションによるコミュニケーション創発機構 の構成と解明 (タイプ A)」の援助を受けた .

\section{$\diamond$ 参 考 文 献 $\diamond$}

[Asada 01] Asada, M., MacDorman, K. F., Ishiguro, H., and Kuniyoshi, Y.: Cognitive developmental robotics as a new paradigm for the design of humanoid robots, Robotics and Autonomous Systems, Vol. 37, pp. 185-193 (2001)

[Baron-Cohen 95] Baron-Cohen, S.: Mindblindness, MIT Press (1995) 
[Breazeal 00] Breazeal, C. and Scassellati, B.: Infant-like Social Interactions between a Robot and a Human Caregiver, Adaptive Behavior, Vol. 8, No. 1, pp. 49-74 (2000)

[Bremner 94] Bremner, J. G.: Infancy, Blackwell (1994)

[Butterworth 91] Butterworth, G. E. and Jarrett, N. L. M.: What minds have in common is space: Spatial mechanisms serving joint visual attention in infancy, British Journal of Developmental Psychology, Vol. 9, pp. 55-72 (1991)

[Dominguez 01] Dominguez, M. and Jacobs, R. A.: Visual Development and the Acquisition of Binocular Disparity Sensitivities, in Proceedings of the Eighteenth International Conference on Machine Learning (2001)

[Elman 96] Elman, J. L., Bates, E. A., Johnson, M. H., Karmiloff-Smith, A., Parisi, D., and Plunkett, K.: Rethinking Innateness: A connectionist perspective on development, MIT Press (1996)

[乾 01] 乾敏郎, 安西 祐一郎 (編) : 認知科学の新展開 1 -認知 発達と進化, 岩波書店 (2001)

[石村 92] 石村 貞夫 : 分散分析のはなし, 東京図書 (1992)

[Johnson 97] Johnson, M. H.: Developmental Cognitive Neuroscience, Blackwell (1997)

[Kozima 01a] Kozima, H. and Yano, H.: A Robot that Learns to Communicate with Human Caregivers, in Proceedings of the First International Workshop on Epigenetic Robotics (2001)

[小嶋 01b] 小嶋 秀樹, 高田 明: 社会的相互行為への発達的アプ ローチ - 社会のなかで発達するロボットの可能性 - , 人工知能 学会誌, Vol. 16, No. 6, pp. 812-818 (2001)

[Metta 99] Metta, G., Sandini, G., and Konczak, J.: A developmental approach to visually-guided reaching in artificial systems, Neural Networks, Vol. 12, pp. 1413-1427 (1999)

[Metta 01] Metta, G., Sandini, G., Natale, L., and Panerai, F.: Development and Robotics, in Proceedings of the IEEE-RAS International Conference on Humanoid Robots, pp. 33-42 (2001)

[Moore 95] Moore, C. and Dunham, P. J. eds.: Joint Attention: Its Origins and Role in Development, Lawrence Erlbaum Associates (1995)

[Newport 90] Newport, E. L.: Maturational Constraints on Language Learning, Cognitive Science, Vol. 14, pp. 11-28 (1990)

[Scassellati 02] Scassellati, B.: Theory of Mind for a $\mathrm{Hu}-$ manoid Robot, Autonomous Robots, Vol. 12, pp. 13-24 (2002)

[多賀 02] 多賀 厳太郎 : 脳と身体の動的デザイン - 運動・知覚の 非線形力学と発達, 金子書房 (2002)

[Uchibe 98] Uchibe, E., Asada, M., and Hosoda, K.: Environmental Complexity Control for Vision-Based Learning Mobile Robot, in Proceedings of IEEE International Conference on Robotics and Automation, pp. 1865-1870 (1998)

\section{〔担当委員 : 岡 隆一〕}

2002 年 11 月 6 日 受理

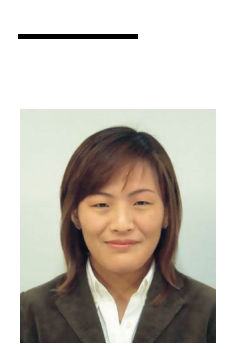

\section{紹 介}

\section{長井 志江}

1997 年青山学院大学理工学部機械工学科卒業. 1999 年 同大学大学院博士前期課程修了. 同年大阪大学大学院工学 研究科知能・機能創成工学専攻博士後期課程入学. 2002 年 10 月単位取得退学. 同年 11 月同大学大学院工学研究 科産学官連携研究員となり現在に至る.認知発達ロボティ クスの研究に従事

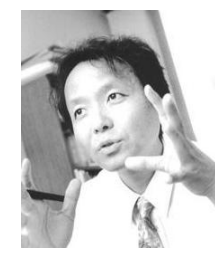

\section{浅田 稔(正会員)}

1982 年大阪大学大学院基礎工学研究科後期課程修了. 同 年大阪大学基礎工学部助手. 1989 年大阪大学工学部助教 授. 1995 年同教授. 1997 年大阪大学大学院工学研究科 知能・機能創成工学専攻教授となり現在に至る. この間， 1986 年から 1 年間米国メリーランド大学客員研究員 . 知 能ロボットの研究に従事.1989 年情報処理学会研究賞、 1992 年 IEEE/RSJ IROS'92 Best Paper Award 受賞. 1996 年日本ロボット学会論文賞受賞. 2001 年度 文部科学大臣賞科学技術普及啓発功績者の表彰. 博士 (工学).ロボカップ国際 委員会会長. 阪大 FRC ロボカップヒューマノイド研究プロジェクトリーダー 日本ロボット学会, 電子情報通信学会, 情報処理学会, 人工知能学会, 日本機械 学会, 計測自動制御学会, システム制御情報学会, IEEE R\&A, CS , SMC societies などの会員 .

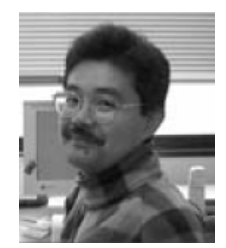

\section{細田耕}

1993 年京都大学大学院工学研究科機械工学専攻博士後期 課程修了. 同年大阪大学工学部助手. 1997 年同大学大学 院工学研究科助教授となり現在に至る。の間, 1998 年 から 1 年間スイスチューリヒ大学客員教授.ビジュアル サーボ, 知能ロボットの研究に従事. 博士 (工学) . 